\title{
DIVIDED SOVEREIGNTY: EMPIRE AND NATION IN THE MAKING OF MODERN BRITAIN
}

APRIL 2009

By

Andrew Baker

Lecturer in History

University of Hertfordshire 


\begin{abstract}
Great Britain is regarded as a classic example of the Weberian state, and thus as a model of a developed state that might be contrasted with developing states. However, this comfortable fiction conceals the role of empire in the evolution of the British state. Rather than take the distinction between a 'metropolis' and a 'periphery' as given, this essay explores the mutual constitution of state and empire. What it finds is that the political identity of the British state changed drastically over the first half of the twentieth century, as British intellectuals and policymakers attempted to develop a new political community through the British Commonwealth. The British state of the interwar years decentralised its decision-making and embedded itself firmly in new multilateral networks. A rationalised, centralised British state only emerged after the Second World War, and that in the context of other (Atlantic and European) political identities. The modern British state, it is concluded, is as much a post-colonial invention as the states of the 'developing' world.
\end{abstract}




\section{INTRODUCTION}

Britain occupies an important place in theories of the state and sovereignty. From the perspective of historical sociology, Britain exemplifies the development of the fiscalmilitary state, where clerks and administrators made possible the exploits of British military heroes, Marlborough to Wellington, Vernon to Nelson (Brewer, 1989). From the perspective of historical materialism, Britain exemplifies capitalist development, an essentially 'universalising' world market concealed behind a bureaucratic, centralising nation-state (Rosenberg, 1994).

There is general agreement that, by the late eighteenth century, a modern, powerful British state had emerged, under the Crown-in-Parliament, forged to make war and forged, as a nation, in war (Colley, 2003). Why this happened, the precise mechanisms involved, is a subject of major disagreement. There have been several attempts at a grand synthesis of Weberian (state-via-coercion) and Marxian (state-via-capital) thought. Benno Teschke (2003) has dated the revolution in European international relations to 1688, arguing for a connection between English capital, European wars, and the emergence of the state system. Charles Tilly (1992) has placed state development on two axes, capital and coercion, and has posited that the early development of a modern British state was founded upon an alliance between the Crown and English burghers and merchants. Michael Mann (1993), in a massive survey, has developed a theory along four axes, ideological, economic, military and political. Other scholars have attempted to move away, in novel ways, from Marx and Weber. Hendrik Spruyt (1994) has suggested that modern state development was a process of 'survival of the fittest,' in which states, eventually, triumphed over city states and city leagues. John Ruggie (1993) has posited that the modern state system emerged as a confluence of logically separate phenomena, particularly in the realms of material organisation, social opportunities, and social 'epistemes.'

All of these theories have two characteristics in common: first, they all posit that modern state development has followed some kind of 'trajectory' of convergence between a rationalising state and a nationalising civil society; second, they all contrive to ignore empires. Mann (1993) notes, at the very outset, that he will only address empires inasmuch as they affected the state (which was not at all, apparently); Tilly (1992) briefly notes that 'systems change,' after 1945, brought about the end of empire; Brewer (1989) occasionally mentions the East India Company, in connection with administrative and fiscal developments in London; Teschke and Ruggie ignore the phenomenon of empire entirely. Spruyt (2005) has written an interesting work on decolonisation, but follows the traditional line that empires were convenient (or not) addenda to (fully) developed, rational, gain-maximising western states. If a theory of imperial 'peripheries' did not exist, clearly, it would be necessary to invent one.

The 'trajectory' thesis, the belief in the convergence, in modern states, between the government and the governed, lies at the heart of theories of sovereignty, explaining how and why modern states establish supremacy over all other authority within a population, and how and why they come to recognise that authority in other states (Hinsley, 1986; 
Bull, 1977). These two aspects of sovereignty, internal and external, allow 'empiricists' to treat the relations between national states as the central problem of politics (Morgenthau, 1978), and 'idealists' to explore the normative and constitutive forces comprising 'sovereignty' as an abstraction (Beitz, 1991).

It is unsurprising that theorists interested in sovereignty should dismiss or avoid empire: empires were untidy things, with little in the way of a neat division between internal and external authority. The very concept of empire makes it difficult to treat sovereignty as an indivisible, universal thing and/or idea. Edward Keene (2002) has noted that, beyond the European society of states, 'the fundamental normative principle of the colonial and imperial systems... was that sovereignty should be divided across national and territorial borders as required to develop commerce and to promote... good government.' Divided sovereignty has left its legacy: whereas many scholars 'have consistently misrepresented the contemporary practice of dividing sovereignty as an unprecedented, 'post-modern' or 'post-Westphalian' phenomenon,' the tension between a 'tolerant' society of states, and a 'civilising' world of empires is as old as modern sovereignty.

This essay will examine the phenomenon of 'divided' sovereignty. However, where Keene (2002) seeks to draw a line between practices inside of Europe, that is, where a society of states was established, and outside of Europe, that is, the realm of civilising empires, this essay will examine the implications of divided sovereignty for the metropolitan heart of empire in London. This essay will argue that the practice of dividing sovereignty, in order to run the empire, produced a political and social crisis of self-interest in Britain in the mid-twentieth century. As it became more difficult to determine whether the metropolis was pushing, or the imperial periphery pulling, the imperial enterprise, the British responded with a radical shift in focus, away from Empire, towards Europe and the Atlantic alliance.

The British Empire had a profound effect on British politics. If sovereignty is a restatement of the permanent problem of political authority and obligation within a community (Hinsley, 1986), the permanent problem of the British Empire was ascertaining whose authority lay in which community. So far from following a rationalising 'trajectory,' British sovereignty—legitimacy, political power, decisionmaking authority - actually came unravelled during the first half of the twentieth century, as the imperial 'periphery' sought to control London, and as London developed new ways to control her periphery. Efforts to address the varied legacy of empire have focused upon the 'problem' of the 'developing' world (Jackson, 1990; Bull and Watson, 1984). This assumes post-colonial societies entered into an existent (idealised) European society of states, rather than the entry of all parties, colonised and coloniser, into a new phase in global politics.

This essay will examine the period 1898 to 1962 . It will argue that this period witnessed a major contest between 'national' and 'imperial' forms of sovereignty, as the British state was pulled in different directions by competing interests and communities within the Empire. Generally, this debate took place beyond the public view (Darwin, 2005b). This period may be broken into three segments. Between 1898 and 1919, national sovereignty 
became a major problem in British politics, as it became clear that British interests were not always well-served by the Empire, and as resistance to British power took shape in various quarters. This prompted two experiments in managing nationalism: the British Commonwealth and the League of Nations. Between 1919 and 1945, these two experiments pulled British authority in new directions, making it difficult for Britain to make 'autonomous' decisions as a state. Between 1945 and 1962, there was a concerted effort to reassert British authority in London, culminating in the development of a nuclear deterrent through the Anglo-American relationship, and the beginning of an exclusive economic relationship with Europe.

This essay will cast doubt upon theories of state development which posit a 'trajectory' in the development of national-states, while suggesting that the modern state, so far from being a creature of the eighteenth century, has continually evolved. The modern British state is a recent invention, as post-colonial in character as the formerly subject peoples of the 'developing' world.

\section{Power AND the Evolution of A 'Political Community,' 1898-1919}

Between 1898 and 1919, the fact that the British Empire was not a political community became problematic. The policy-making elite, in London, responded to this challenge by trying to make it into a community. That is, they attempted to build a broad sense of 'wefeeling' across their empire, in which there was broad identification of mutual selfinterest, and in which mutual attention, communication and responsiveness would facilitate common decision-making, to the benefit of all. This found expression in the Commonwealth, and was replicated in the League of Nations.

\section{Race, Arms and the Boer War}

Force is a sine qua non of the modern state; and yet, even as the modern British state took shape in the late eighteenth century, British arms multiplied. By the latter half of the nineteenth century, when Benjamin Disraeli insisted that Queen Victoria be made 'Empress of India,' the British Prime Minister was two individuals: the appointed leader of a somewhat representative government commanding a powerful navy off the European coast, and the autocratic master of a far-flung Asian despotism with an immense standing army in the Indian Ocean (Metcalf, 2005). By 1880, the Indian Army was more than half

a million men strong, including part of the British Army. It was a secret army, beyond the public eye: its budget was not voted by Parliament, its upkeep did not burden the taxpayer, and its utilisation was not subject to the whim of press or popular sentiment. This army was Britain's enforcer, criss-crossing the world throughout the nineteenth century to impose imperial power (Robinson and Gallagher, 1981). 
The British Empire was underwritten by non-British soldiers. This astonishing fact is virtually forgotten today; even Indian nationalists were more worried about Britain's domestic management than about the use of an 'indigenous' army for 'foreign' expeditions (Ambekar and Patwardhan, 1962). The real heart of British power was the Indian Army; yet it was so far beyond the attention of the British nation, or of commentators since, that a century of savage global war is still called the pax Britannica.

The Boer War thus came as a rude shock to the British public, making the Empire the subject of a new debate. This was so because the Indian Army did not take part - the Boer War was a white man's war. ${ }^{1}$ Since white men fought it, they also asked (as Indian nationalists, particularly, had been asking for some time), whom did the Empire serve, and to what end? The answer was unclear. The war revealed a deep quandary between forcing 'civilisation' upon the Boers, or tolerating their treatment of 'outlanders;' this posed a seemingly intractable problem of race and nationality, sovereignty and administration. The problem was double-edged: British manhood was also put to the test in the war, and Britain's ability to project power to its farthest frontiers.

The question of strength was racial and political. It was also moral; Lord Elgin, for instance, spoke of 'the struggle between civilisation and barbarism which is going on more or less all over the world' (Hyam, 1975). Yet civilisation was imposed by naked force upon South Africa; this posed a moral puzzle, potentially undermining the civilising argument, and animating a liberal critique of the British Empire.

The liberal critique of empire focused upon domestic, i.e. British, mismanagement, particularly in the social conditions of the working classes, an argument most effectively put by J.A. Hobson. In this respect, liberalism vindicated a change in imperial policy which was hardly liberal: the South Africa Act of 1909 created a single Union, in which the Boers formed the majority. The racial policies of the Boers, one of the only genuine grievances against them, were now applied to the whole country. While liberalism experienced a great triumph in Britain after the war, the British fed a virulent strain of Boer irredentism, and inspired two countervailing nationalisms: an Indian movement, led by M.K. Gandhi from 1909, and an African movement, led by John Dube from 1912.

\section{Commonwealth and Empire}

The Boer War highlighted the strange fragility of the Empire. 'Our two greatest national dangers at present,' Lord Cromer opined, 'are backwardness in education and unsound finance;' it was necessary to 'open the way to a better order of things... without in any way endangering all that is essential in the policy of modern Imperialism' (Cromer, 1903). The war was just as much a moral problem for conservatives as for liberals, revealing a stubbornly inefficient army and a passionately uncomprehending population. The army might be reformed; unpredictable popular sentiment, now of a nationalist, now

\footnotetext{
${ }^{1}$ At least in theory. More than 10,000 Africans were armed for various purposes (Pakenham, 1979).
} 
a socialist character, was more troubling. Henceforth, the average Briton was an object of suspicion, the 'Continental commitment' a thing to be avoided (Strachan, 2001).

British statesmen and academics took these problems seriously: the Empire was reinvented, a genuine political community was to be created. As Lionel Curtis, who accompanied Alfred Milner to South Afirca, wrote in 1907:

it begins to dawn on one that South Africa is a microcosm and much that we thought peculiar to it is equally true of the Empire itself. We want some clear and coherent scheme before men's minds of what the Empire can and should be (Lavin, 1982).

Cooperation in the common interest became the motivating ideal in Oxford, Chatham House, the Round Table, and Whitehall; it gained legal status during the 1907 Colonial Conference, when Wilfrid Laurier proposed the title 'self-governing Dominions' to distinguish Canada, Australia and New Zealand (and eventually Eire and South Africa) from the 'dependent' empire. The Committee of Imperial Defence, an informal advisory body under Arthur Balfour's premiership, became an official organ of Commonwealth consultation. This idea was fully expressed in Dominion participation in the Imperial War Cabinet during the Great War, and propounded in the writings of a new 'Oxford' school of imperial historiography that was led by Lionel Curtis from All Souls.

The Commonwealth was a radical reinterpretation of 'Britishness' to incorporate a multiracial institution, initially Irish, Quebecois and Afrikaner, but later 'Asiatics' and Africans. It was never particularly successful in practice, but the expansion of England was now justified by the spread of English institutions and the attainment of full Dominion status within a free, equal Commonwealth. From Oxford, the prophets of a multi-racial Commonwealth addressed the problems of race and nationality, empire and freedom. The British Commonwealth of Nations (the term received official recognition in 1917) was to be an organic unit with a distinct teleology. Thus would British power be preserved in an unified political community.

\section{The Commonwealth Ideal and the League of Nations}

The emerging Commonwealth ideal was a 'political community,' bound together by common sentiment and shared values. It was not limited to the Britannic world. As Leonard Woolf (1916) concluded his classic work on international government,

In the British Empire and other loosely federated States, we see the beginnings of another system of government, and one to which International Government would necessarily approximate.

The British Empire, he added, was solving problems of nationalism and rival interests, because it was blurring the line between the independent and dependent Empires. 
Woolf's observation highlighted an important connection between the League and the British Empire, which becomes more important when we consider that the British peace movement made few practical contributions to the League or interwar order (Ceadel, 2000). It was people like Robert Cecil or Jan Smuts, supported by academics like Charles Webster, Alfred Zimmern and A.F. Pollard, who created the League. To these men, universal peace and imperial peace were the same thing. As Pollard (1919) observed,

the only political system which approached the idea of a League of Nations was the British Empire, and it achieved success, not by the amalgamation of independent units, but by their decentralization.

These men inhabited a world of Empires, not national states; to Zimmern (1934), the League was akin to the British Commonwealth or the Austrian Empire: an invention of necessity. As the empires of the Continent disintegrated, the League, like the Commonwealth, was a reinvention of empire, reconciling competing nationalities to transnational security, law and arbitration, good government, economic well-being and cross-border cooperation (Goldstein, 1991). If such a view gave moral comfort to policymakers such as Robert Cecil, it was also true that they were searching for a means of eliminating the troubling distinctions between the imperial metropolis and its diverse periphery, and thus regarded the League as a kind of perpetual imperial conference (Cecil, 1971). Jan Smuts (1918) wrote the clearest exposition of these views, arguing the League ought to possess the following key characteristics: (a) that ultimate authority should rest in the constituent states (as in the Imperial Cabinet), without forcing great powers to submit to the small; (b) that trusteeship should be exercised over minor constituents (as in Crown Colonies or Protectorates); (c) that trusteeship territories ought to be regulated by open-door economics and non-military police (as in Crown Colonies or Protectorates).

Surely this was a British corruption of American idealism? Not in the slightest: it was the British who first pressed for a League. Edward Grey was convinced that a conference would have averted the war, and that a permanent conference ought to be maintained after the war. Colonel House, on his first wartime visit to London, wrote Wilson,

There was one thing Grey was fairly insistent upon, and that was that we should come into some general guaranty for world-wide peace. I evaded this by suggesting [a convention on] the principles upon which civilized warfare should in the future be conducted (Seymour, 1926).

What Grey proposed was the regulation of ius ad bellum; House responded with a proposal dealing with ius in bello. There is a difference, albeit one many League historians ignore when pointing to the Hague Convention as though it were parent to the League idea. On 22 September 1915, Grey renewed his suggestion:

the great object of securing the elimination of militarism and navalism is to get security for the future against aggressive war... Would the President propose that there should be a League of Nations binding themselves to side against any Power which broke a treaty; 
which broke certain rules of warfare on sea or land... or which refused, in case of dispute, to adopt some other method of settlement than that of war? (Seymour, 1926)

Over the next several months, Wilson came round to Grey's view. In mid-1916, Wilson suggested a joint declaration between Britain and America, based on the 22 September letter.

Grey demurred: allies had to be considered, and an Anglo-American declaration would not be possible. Wilson made his declaration, before the League to Enforce Peace, alone. To Wilson's mind, it was necessary for America to enter the war for the right reasons; nevertheless, the League was as much a British invention as it was an American. It had more in common with the imperial conferences than the Geneva Convention. Wilson championed the idea, true, but America rejected it, while Britain made it her own. This had nothing to do with peace movements; rather, the League reflected the emerging elite consensus that had grown up in Britain in respect of the Commonwealth.

Why didn't Grey make the joint declaration? G. Trevelyan (1940) posited a simple explanation: that he meant what he said, that he had to consider (as Wilson never considered) the views of Russia, France and Italy. Instead, he encouraged Wilson to become the proponent of the idea, perhaps because he thought it would bring America into the war, or because he felt that Americans would never accept it unless it were seen to emanate from their own shores.

By 1919, British imperialism had changed radically: imperial expansion took place under the mandatory system of the League, even as the self-governing Dominions asserted their authority in London. The challenge was to preserve the long-term basis of British power while answering liberal and nationalist claims. The future lay in the political communities of the League and the Commonwealth: a new model of 'enlightened' selfinterest appeared to have been born.

\section{INDECISION AND DISAPPOINTMENT, 1919-1945}

The Boer War created a crisis in imperial relations. Yet, liberal and nationalist critiques of Empire, so far from prompting statesmen in London to limit themselves to the British state, spurred them to cast their ambition still further afield. London was thrown open as never before or since to the statesmen of the British Empire: power and authority were to be shared under the Crown, decisions were to serve common interests. Here was a new model of political power, which was explicitly meant to transcend boundaries of state or nation. British sovereignty became indistinct: external recognition of British power came to depend upon the Commonwealth, which was difficult to control and even more difficult to explain; internal British authority came to depend upon broad multilateral negotiation and deal-making, giving peoples on the other side of Earth a say in 'British' affairs. 
The interwar years were a high point of British internationalism. Major policy decisions were made with reference to Commonwealth statesmen. This was reflected by the creation of a Dominions Office in 1925, and then the appointment of a Dominions Secretary in 1930 (Palmer, 1934). A reverse colonisation took place: as the Dominions gained more constitutional guarantees of their sovereignty, they dispatched their best statesmen to London. Dominion penetration in London was not, and could not be, reciprocated. This became apparent in a series of hard choices - the Ottawa Accords, the abdication crisis, policy towards Germany - in which Britain was forced to adopt the Commonwealth line. During the war, the Chiefs of Staff moved away from the Commonwealth model, initiating a struggle over the nature of post-war British policy. By 1946, concepts like 'imperial defence' and a multilateral ideal of Commonwealth relations were dead. Instead, British relations were to be based on bilateralism, which represented a reassertion of 'British' sovereignty. In future, interest would come before community; Britain would act once more as a free agent.

\section{Commonwealth Evolution}

Constitutionally, the interwar British Empire became difficult to explain or predict, with no clear lines for collective decision-making. This was a cause of much official smugness: 'it defies classification and bears no real resemblance to any other political organization,' according to the 1926 Inter-Imperial Relations Committee (Cronkite, 1938). In the same year, Alfred Zimmern (1934) described the Commonwealth as a British Entente, each state having full control over its policy but bound to the whole by cordial feelings. It was averred, in London and the Dominions, that Commonwealth unity and state autonomy were reconcilable, just so long as nobody thought too hard about it (Long, 1937). The Dominions enjoyed liberty under the law of the King, who moreover symbolized the ultimate sovereignty of Britain and embodied, for many, the sentimental bonds of King and Country (Zimmern, 1934).

Legally, Dominion sovereignty was established by the end of the 1920s. In the Chanak crisis of 1923, the Dominions condemned Lloyd George for risking war with Turkey, publicly refuting his claim to lead the Empire. A fuller guarantee of Dominion sovereignty was provided by the Statute of Westminster, by which 'no law and no provision of any law made after the commencement of this Act by the Parliament of a Dominion shall be void or inoperative on the ground that it is repugnant to the law of England' (Statute of Westminster, 1931). The Dominions were effectively sovereign, though New Zealand did not bother to ratify the Statute until 1947.

If the British Empire was a license for the Dominions to continually involve themselves in the affairs of London, the Statute of Westminster barred London from doing the same in Ottawa or Canberra. Throughout the 1930s, the capacity of the Dominions to so involve themselves developed rapidly, as the Dominions each opened their own Department of External Affairs (New Zealand was the last to do so, in 1942), opened 
consulates, appointed ministers and exchanged High Commissioners. The Governors General now represented what the King represented: a symbolic head of state.

In 1937, New Zealand's premier, M.J. Savage, averred that 'we have found no difficulties, and expect to find no difficulties, in conducting the affairs of our Dominion with complete freedom' (Cmd. 5482, 1937). It was otherwise for Britain.

\section{Hard Choices: Ottawa and Abdication}

The economic and political environment of the 1930s placed a tremendous strain upon Britain, forcing her to rely upon the Commonwealth. During the Ottawa Conference and the abdication crisis, the Dominions were able to drive the pace of British policy on issues, Sterling and the Crown, at the heart of British sovereignty.

The Ottawa Conference, in 1932, followed close on the heels of the Statute of Westminster. Already, British statesmen dreamt of the day when scientific development in West African colonies would pay off Britain's debt (Hancock, 1940). By 1925, economic parity was achieved with 1913, and tariff barriers went down, but structural problems ran deep. British goods became less competitive, British finance more conservative, there were large American debts, there weren't large wells of 'invisible' assets in shipping or insurance to cushion trade deficits (Cain and Hopkins, 1993). The buoyancy of the British economy in such trying times depended upon Sterling; Sterling depended upon circulation and reserve throughout the Empire-Commonwealth. The Dominions thus possessed extraordinary leverage over British economic policy (Drummond, 1972). The Dominions wanted to open British markets: Britain's desire to preserve Sterling as a trading/reserve currency overrode her desire to protect domestic producers or maintain other, more efficient, trade partners. These were the conditions under which the Commonwealth met at Ottawa.

In fact, Canada did leave Sterling, but still participated in the Ottawa Conference (Holland, 1983). Fierce competition took place in a cooperative setting. This produced contradictory results. The New Zealand delegation, for instance, arrived presuming British benevolence would equal British concessions (Capie, 1978). Britain was desperate for the negotiations to succeed: it was rumoured Stanley Baldwin told his delegation to take whatever they could get (Drummond, 1972). Australia and New Zealand threatened walkouts over Argentine beef; South Africa settled for the maintenance of the status quo; Canada imposed a last-minute duty on British steel plate which nearly caused a British walkout; Eire was already engaged in an economic 'war' with Britain, and so (ironically) passed an opportunity to damage Britain's position. Britain's trade deficit worsened: British markets were forced open, British exports suffered as retaliatory measures were taken outside the Commonwealth (Cain and Hopkins, 1993). Ottawa reversed the Marxian view of metropolis-periphery: it was Britain that was thoroughly penetrated by the Empire. 
The British preserved Sterling, but left a lot of blood on the floor at 'Rottawa,' as Churchill called it (Amery, 1988). Ottawa demonstrated the peril of treating sovereign states as friends. Sentiment and imperial unity did not go hand in hand with hard bargaining (Rooth, 1986). Indeed, as the abdication crisis demonstrated, the sentiment of faraway lands was a hard master. The crisis was sparked by North American press coverage of the affair between the King and Mrs. Simpson. Mackenzie King, the Canadian Premier, privately apprised Stanley Baldwin of the danger that the affair posed to imperial sentiment (Mansergh, 1952). Stanley Bruce, the Australian High Commissioner, persuaded Baldwin to act (Edwards, 1980).

The first question was sentimental: did the Dominions prefer abdication in favour of the Duke of York, or a morganatic marriage? As the South African premier, General Herzog, said: 'the one would be a great shock, the other would be a permanent wound' (Mansergh, 1952). The other Dominions concurred on this point, which overrode British preference for a morganatic marriage.

The second question was legal, and demonstrated the capacity of the Dominions to change the nature of the Commonwealth through independent political action. Every Dominion which had ratified the Statute of Westminster also had to approve the abdication of the King. For Australia, New Zealand and Canada, which were included in the Declaration of Abdication Act of the Westminster Parliament, this did not present a problem. South Africa refused to be included in the action of the Westminster Parliament, and so dated the abdication from the demise of the King, on 11 December, rather than on 10 December, which was when the Act was passed (Bailey, 1938). The Irish approach was more radical still, seizing the opportunity provided by the abdication to give 'external association' a clear position in Irish law. The King's authority was subjugated to the Executive Council, while diplomatic representation and international agreements became the sole domain of the Council. The Executive Authority (External Relations) Act (1936) came into effect on 12 December, meaning that the King reigned an extra day in Ireland. If the Dominions were content to remain 'free and equal' nations under the sovereignty of the King, that sovereignty had become very thin indeed by the beginning of 1937.

\section{More Hard Choices: War and Defence}

As British sovereignty became divided between the Dominions, so her capacity to respond to the European balance of power also became divided, allowing faraway peoples a direct say on questions of vital and immediate importance. Britain officially identified Germany as a major threat in 1935, when Neville Chamberlain initiated rearmament (Peden, 1979). Despite Chamberlain's public identification of the threat of Nazism (Feiling, 1946), and his argument that Hitler was the 'bully' of Europe (Macleod, 1961), his reputation has never recovered from 'appeasement.' One reason is that onetime supporters like E.H. Carr found it convenient to repudiate him; another is that the diplomatic constraints imposed by the Commonwealth are often ignored. 
The Commonwealth wavered prior to 1939. The common 'milieu' goals of the Commonwealth (international law, prosperity, etc.) concealed deep divisions of interest and priority (Round Table, 1938). Had war come in 1938, Lord Halifax was convinced that South Africa would have remained neutral; that there would have remained strong opposition to war in Australia; and that the attitude of Canada would have been uncertain (Birkenhead, 1965). This was a critical problem: Britain identified herself as the British Empire, but was unable to tell whether the Empire would support her in war.

The Imperial Conference of 1937 made it apparent that the Dominions were not happy to prepare for another war, let alone wage one. The Dominions insisted upon their parliamentary right to decide; while Britain might subscribe to the League of Nations, the Dominions, rather like the USA, remained aloof (Hodson, 1939). The conference was a brutal demonstration of the limits of Commonwealth cooperation: each Dominion had a good reason to avoid standing behind Britain. Mackenzie King cited secessionist fears in the Canadian plains and in Quebec; Hertzog insensibly compared Versailles to Vereeniging; M.J. Savage suggested giving the League some real 'teeth;' the Australians cited their concern over Japan (Ovendale, 1975). The conference concluded with a lame statement of faith in the capacity of nations of all creeds to cooperate (Cmd. 5482, 1937).

Britain could not contemplate waging a major war without the vast material and manpower resources of the Dominions. Yet, as Sir Harry Batterbee wrote, Dominion attitudes were

hopelessly inconsistent: they blame us for not being prepared to stand up for democratic principles but are not ready to commit themselves in any way to come to our help if we get into trouble as a result of standing up to the dictator powers (Batterbee, 1938).

British policy was bound to the Commonwealth, and the Commonwealth had demanded peace at any price. As Anthony Eden observed, it was

clear that the Dominions were isolationist and there would be no sense in fighting a war which would break the British Empire while trying to secure the safety of the United Kingdom (Watt, 1965).

Even the annexation of Czechoslovakia failed to provoke any response from the Dominions: Neville Chamberlain risked the disintegration of the Empire when he declared war. Canada nearly broke: Ernest Lapointe, the external affairs minister, made an unprecedented intervention in provincial politics to defeat secessionists in Quebec (Rumilly, 1973). So too South Africa: Jan Smuts became premier because the Governor General refused to call an election, but nationalist revolt was a possibility (Nicholls, 1961). None of the Dominions offered immediately to dispatch an expeditionary force, but once the Dominions had cast their lot with Britain, they found their publics demanded further action. 


\section{British Post-Hostilities Planning: A Return to Sovereignty?}

The Second World War framed the experiments of the interwar years in a sinister light. The interwar Commonwealth had privileged legitimacy over pragmatism, imposing inconvenient multilateral constraints on policy-making; changes had to be made. The Chiefs of Staff demanded the ability to plan realistically for the post-war era, that is, to assume that Russia would be relatively hostile, and that the post-war world would consist of competing power blocs. In this sort of world, the Chiefs of Staff derived their model of cooperation from the Combined Chiefs of Staff, in Washington: a bilateral special relationship between the United States and the British Empire, combining the unbounded industrial strength of the one with the unlimited real estate of the other (Lewis, 2003).

The 'realism' of the Chiefs of Staff was tempered by the understanding in the Foreign Office that substantial components of 'British' power, especially in new military technologies like aviation, resided in the Commonwealth: it was unlikely that India or Australia would continue to contribute their military manpower to an exclusive AngloAmerican concern (Report of a meeting at Balliol, 1942). ${ }^{2}$ This presented a conundrum: to maintain Anglo-American cooperation on grounds of equality, Commonwealth cooperation had to continue.

One way of making this work was to integrate Commonwealth power into a more general framework. This consideration informed the 'Four Power Plan' (WP(42)516, 1942). In this plan, a general settlement (i.e. the United Nations) aimed to preserve engagement of the great powers in global order and security. If such a plan succeeded, so much the better; if it failed, it would leave Britain, America and the Commonwealth committed to one another under the distinctly unsuspicious banner of world unity. In substance, this was the Commonwealth or League ideal of the interwar years; in form, it was no longer 'Britannic.'

Pressure from Ernest Bevin forced the Chiefs of Staff to acquiesce to the diplomatic worldview. Privately, the Chiefs of Staff simply altered their rules of secrecy in order to continue to plan as they wanted, without the interference of the Foreign Office or busybody ministers (COS13(44)346, 1944). For the benefit of the Cabinet, the Chiefs of Staff recognised that the emergence of a general settlement would probably involve America and the Dominions in global geopolitics and thus provide a foundation for greater cooperation with Britain (JP(44)87, 1944). When the general settlement failed, the Chiefs of Staff would be ready, and America and the Dominions would move even closer.

During the war, British thinking became more instrumental. Interest had to precede community: it was no good appealing to some airy attachment to the Union flag. Moreover, the great imperial periphery of the interwar years, which had been Britain's margin of security, ceased to be great: aviation and the atomic bomb made it a small place indeed, making the consolidation of British policy more necessary than ever.

\footnotetext{
${ }^{2}$ Balliol was where the Foreign Research and Press Service was located. Its staff included Arnold Toynbee, Lionel Curtis, and Alfred Zimmern.
} 


\section{DECOLONISATION, POLARIS AND EUROPE, 1945-1962}

While recent studies have emphasised revival in post-war British imperial politics (Martel, 2000), the fact remains that after the war the direction of the imperial project changed radically, as the imperial metropolis forcibly asserted itself. A new politics of pragmatism, associated with Harold Macmillan and Malcolm MacDonald rather than Winston Churchill and Robert Cecil, dictated that the Empire either serve Britain, or be cut loose. In many places, the result was administrative centralisation and purposeful economic development; but many other places were cut loose, in a businesslike process that became progressive as the British state adapted to post-war realities.

This businesslike attitude was itself indicative of deep-seated changes in the order of British priorities. There can be no doubt, as Roger Louis (1977) has demonstrated, that the British fought the war to defend or even extend the Empire. To many observers - and certainly to critical Americans - there was an astonishing continuity in British policy: the economic potential of the Empire was to be realised through scientific development, the strategic potential realised through rationalisation. Yet there was a vital difference: as Taylor (1992) argued, 'the British did not relinquish their Empire by accident. They ceased to believe in it.'

A new strain of British scepticism - one which ran far beyond the Chiefs of Staff revealed itself almost immediately, as Commonwealth cooperation shifted from a multilateral to a bilateral model. During the interwar years, British policymakers had been desperate to ensure that imperial conferences created a facade of imperial unity; in the Dominion Premiers' Meeting of 1946, nobody minded that the Australian premier, Benjamin Chifley, had departed by the time the Canadian premier, Mackenzie King, arrived. The meeting was a running series of consultations: Britain negotiated agreements separately with each player. Australia and New Zealand, for instance, agreed to support Britain publicly in the South Pacific, and to help maintain order in the shattered Japanese periphery. Canada, by contrast, agreed to support Britain privately, particularly in defence liaison and the standardisation of equipment (an agreement which established the standardisation framework for the North Atlantic alliance), but also in atomic research. The Foreign Secretary, Ernest Bevin, was the architect of this new framework for imperial relations: each country in the British Empire would be dealt with in its particular regional political and economic context. ${ }^{3}$ Imperial unity, with all that implied for a common British identity around the world, was replaced with overlapping 'defence areas,' each serving specific purposes within the context of a British world system.

\footnotetext{
${ }^{3}$ It may be observed that Bevin's position as Foreign Secretary was significant for two reasons: his policy brought the Foreign Office closer to the Chiefs of Staff than hitherto; and his policy emerged out of a long apprenticeship in a range of important interdepartmental committees, where he worked closely with men, like Lionel Curtis or Arnold Toynbee, who had shaped the interwar Commonwealth. Both facts suggest that Bevin's position reflected a subtle yet important shift in the elite consensus about Empire.
} 
The purpose of that system more generally became increasingly vague. British defence planning for an independent India, for instance, had sensibly anticipated that the politics of the Indian Ocean littoral, the proximity of Russia and China, as well as the possibility of partition, would ensure that India continued to cooperate closely with Britain in defence matters. Yet the triumph of Afrikaner nationalism and the beginnings of apartheid on one side of that littoral, coupled with the birth and spread of the non-aligned movement on the other, destroyed any presumptive unity that Britain might have maintained across the Indian Ocean. The administrative logic of the Commonwealth broke down as the old Dominion 'circulars' ceased to circulate: states like Australia and Canada continued to receive high-grade information from London, others like South Africa were given limited information, while suspect or dysfunctional states like India and Pakistan were sent anodyne summaries. As the logic of British imperialism became more instrumental, Commonwealth relations became 'external' rather than 'internal.'

This did not mean that imperial thinking ground to a halt; but the relationship between Britain and the Empire had changed, placing the interests and prerogatives of the former at the heart of decision-making. John Darwin (2005a) has raised the prospect of a 'fourth' British Empire in the immediate post-war decades, organised around an independent nuclear deterrent, strategic bases in the Middle East, and the position of sterling as fortified by imperial preference and the development of the export capacity of the colonial Empire in Africa and Southeast Asia. Nevertheless, the loss of India deprived the Empire of its principle enforcers; the cost of imperial defence now fell directly upon the British taxpayer, making the choice between imperial ventures and social spending more immediate. In this environment, cooperation with America or with Europe each offered potential advantages that had to be weighed, coolly, beside those of Commonwealth cooperation.

The speed and clarity of this transformation may be exaggerated easily. The Suez Crisis is a particularly good example of the danger: a brief incident which prompted a few resignations has assumed a tremendous retrospective significance as harbinger of deep and long-lasting changes, which were not yet deep enough to prompt British entry into the Common Market in 1957, nor yet long-lasting enough to preclude British military action in Jordan in 1958, Kuwait in 1961, or Aden in 1964 (Petersen, 2000). What did mark a decisive shift in the logic of British imperialism was what accompanied these crises and interventions: a persistent, penetrating, and quite often pitiless effort to apprehend the reasons for the British Empire and British statecraft. Just as the fear of decline at the beginning of the twentieth century spurred the British to reinvent their identity in the Empire, so now the fear of decline fifty years later spurred them to tear that vision apart, and to reinvent their identity apart from the Empire (Beck, 2006).

In this context, two transformations were particularly relevant. One was the decision to enter Europe, which reflected a radical shift in focus between 1957 and 1962 . The 1962 Commonwealth Prime Ministers' Conference was a last-ditch effort, spearheaded by Australia, to preserve the system of imperial preference which had been negotiated at Ottawa in 1932. This was a failure; Macmillan was determined to enter the European 
Economic Community, and between 1962 and 1968, Britain dismantled the system of imperial trade, particularly as the maintenance of the Commonwealth system was perceived as one of the chief impediments to British accession to Europe (Ward, 2001).

The second was Anglo-American technology-sharing arrangements. After 1945, the Commonwealth had lain at the heart of British research and development (Reynolds, 2000). In 1960, Macmillan ended Britain's Bluestreak program, on the back of American willingness to sell Britain Skybolt missiles. When Skybolt was precipitously cancelled, Britain negotiated the purchase, under exceptional terms, of Polaris missiles. A credible sea-launched ballistic missile capability provided Britain with the strategic depth that the Empire was supposed to provide, without having to rely on optimistic appraisals (or outright deception) and good fortune in counter-insurgency (JP(56)10, 1956). It may be true, as D.A. Reynolds claims, that this meant a jarring shift towards submarines, and highlighted British dependence on American nuclear technology (Reynolds, 1991), but it alleviated Britain's dependence on Commonwealth research and liberated Britain from 'strategic' bases whose value was always more apparent than real.

The end of the British 'imperial' perspective in policymaking took place in 1968, when the Colonial Office was wrapped into the Commonwealth Relations Office, and the Commonwealth Relations Office became a division of the Foreign Office. The loss of the Colonial Office was particularly significant, since it had more or less singlehandedly preserved the ethos of a special British imperial mission. Between 1930 and 1947, there had been four important ministers responsible for the conduct of various sorts of British foreign policy. Now, there was one. Consolidation meant that, by 1968, the congruence between external and internal characteristics of British sovereignty was stronger than ever before.

\section{CONCLUSION}

This essay supports two of Stephen Krasner's (1993; 1999) arguments. First, sovereignty was and is a response to given political problems, thus continues to evolve. Second, states jettison 'logics of appropriateness' in the pursuit of material self-interest. However, in contrast to Krasner, this essay has demonstrated that 'legitimating rationales' may, in fact, precede the organisation of practical solutions to political problems. The Commonwealth and the League were deployed to meet a range of pressing, fundamentally material, problems, closely related to the changing needs of British power in world affairs. Yet both were invented as a legitimating rationale prior to deployment as pragmatic solutions, because, as a pragmatic solution, they depended upon the consent of constituent elements, demanding that statesmen have a rational expectation that their interests would be recognised and advanced.

The peculiar history of the Commonwealth is a perfect example of one of the 'secret histories' of the modern state that Justin Rosenberg (1994) has highlighted. The projection of the post-imperial state, western or otherwise, backwards into history reflects 
a failure of the historical imagination, which also happens to serve the demand of a totalising institution for teleological certainty. The reverse colonisation of Britain during the first half of the twentieth century suggests that the modern state was a process of coevolution; Manichean distinctions between an imperial 'metropolis' and colonised 'periphery' serve merely to shove the 'periphery' out of the picture, and to endow the 'metropolis' with a wholly false patina of respectability. Perhaps the problem with theories of state development, Marxian or Weberian, is that they remain fundamentally Cartesian, rooted in rationalistic monism no matter how many axes they deploy. If we are to grasp how states constituted one another through colonialism, nationalism and revolt, it might be more appropriate to begin with the existential aphorism, 'je me révolte, donc nous sommes' (Camus, 1951). This would allow us to move away from a gloomy (chauvinistic) narrative of post-war decline for states such as Britain, as well as to avoid the practice (also chauvinistic) of equating modernisation with imagined western norms of 'development.' As Keene (2002) has argued, 'the starting-point for understanding what kind of world order we have today, and what the possibilities are for the future, is to understand the bifurcated, contradictory and discriminatory nature of international order in the past.'

Under such conditions, it is questionable whether any 'general' theory of state formation is desirable, let alone possible. The complicated phenomenon of the British state, constituted as it was in its relations with the British Empire, falsified the Marxist model of capital accumulation at Ottawa, and the Weberian model of war-making in Chamberlain's appeasement; it refuses to follow or establish any particular model of 'sovereignty.' That is precisely why the phenomenon, for all its eccentricities, is too important to ignore. 


\section{REFERENCES}

Ambekar, D. and Patwardhan, R. (1962) Speeches and Writings of Gopal Krishna Gokhale. Bombay: Asia Publishing House.

Amery, L. (1988) The Empire At Bay: The Leo Amery Diaries, 1929-1945. London: Hutchinson.

Bailey, K. (1938) The Abdication Legislation in the United Kingdom and in the Dominions. Politica 3(12): 149-65.

Batterbee, H. (1938) letter to Lord Stanley. National Archives: DO 35/586.

Beck, P. (2006) The lessons of Abadan and Suez for British Foreign Policymakers in the 1960s. The Historical Journal 49(2): 525-47.

Beitz, C. (1991) Sovereignty and Morality in International Affairs. In: D. Held (ed.) Political Theory Today. Cambridge: Polity, pp.236-54.

Earl of Birkenhead (1965) Halifax: The Life of Lord Halifax. London: H. Hamilton.

Brewer, J. (1989) The Sinews of Power: War, Money and the English State, 1688-1783.

London: Routledge.

Bull, H. (1977) The Anarchical Society. New York: Columbia University Press.

Bull, H. and Watson, A. (1984) The Expansion of International Society. Oxford:

Clarendon Press.

Cain, P. and Hopkins, A. (1993) British Imperialism: Crisis and Deconstruction, 19141990. London: Longman.

Camus, A. (1951) l’homme révolté. Paris: Gallimard.

Capie, F. (1978) Australian and New Zealand Competition in the British Market, 19201939. Australian Economic History Review 18(1): 46-71.

Ceadel, M. (2000) Semi-Detached Idealists: The British Peace Movement and International Relations, 1854-1945. Oxford: Oxford University Press.

Cecil, H. (1971) The Development of Lord Robert Cecil's Views on the Securing of a Lasting Peace, 1915-19. DPhil thesis. University of Oxford.

Chiefs of Staff Minutes (COS 13(44)346, 1944). National Archives: CAB 79/82.

Colley, L. (2003) Britons: Forging the Nation, 1707-1837. London: Pimlico.

Conclusions of the Imperial Conference, 1937 (Cmd. 5482, 1937). London: HMSO. 
The Coordination of Defence Policy (JP(44)87, 1944). National Archives: CAB $84 / 62 / 22$.

Cromer (1903) letter to Lord Lansdowne. National Archives: FO 633/6.

Cronkite, F. (1938) Canada and the Abdication. Commonwealth Journal of Economic and Political Studies 4(2): 170-188.

Darwin, J. (2005a) Was there a Fourth British Empire? In: M. Lynn (ed.) The British Empire in the 1950s: Retreat or Revival? London: Palgrave, 16-31.

Darwin, J. (2005b) Bored by the Raj. In: The Times Literary Supplement (16 February).

DEFE 6/34 (JP(56)10, 1956). In: J. Kent (ed.) Egypt and the Defence of the Middle East, part III. London: HMSO.

Drummond, I. (1972) British Economic Policy and the Empire, 1919-1939. London: Allen and Unwin.

Edwards, P. (1980) The Rise and Fall of the High Commissioner: S.M. Bruce in London, 1933-45. In: A. Madden and W. Morris-Jones (eds.) Australia and Britain: Studies in a Changing Relationship. London: Frank Cass.

Executive Authority Act (1936). In: Darwin, J. and Madden, F. (eds.) Select Documents on the Constitutional History of the British Empire and Commonwealth, vol. VI, The Dominions and India since 1900. London: Greenwood.

Feiling, K. (1946) The Life of Neville Chamberlain. London: Macmillan.

The Four Power Plan (WP(42)516, 1942). National Archives: FO 633/6.

Gallagher, J. and Robinson, R. (1981) Africa and the Victorians: The Official Mind of Imperialism. Basingstoke: Macmillan.

Goldstein, E. (1991) Winning the Peace: British Diplomatic Strategy, Peace Planning and the Paris Peace Conference, 1916-1920. Oxford: Clarendon Press.

Hancock, W. (1940) Survey of British Commonwealth Affairs. London: Oxford University Press.

Hinsley, F. (1986) Sovereignty. Cambridge: Cambridge University Press.

Hodson, H. (1939) British Foreign Policy and the Dominions. Foreign Affairs 17: 75363.

Holland, R. (1983) The End of an Imperial Economy: Anglo-Canadian Disengagement in the 1930's. Journal of Imperial and Commonwealth History 11(2): 159-74. 
Hyam, R. (1975) The Partition of Africa: A Critique of Robinson \& Gallagher. In: R. Hyam and G. Martin (eds.) Reappraisals in British Imperial History. London:

Macmillan, 132-164.

Jackson, Robert (1990) Quasi-states: Sovereignty, International Relations and the Third World. Cambridge: Cambridge University Press.

Keene, E. (2002) Beyond the Anarchical Society: Grotius, Colonialism and Order in World Politics. Cambridge: Cambridge University Press.

Krasner, S. (1993) Westphalia and All That. In: J. Goldstein and R. Keohane (eds.) Ideas and Foreign Policy: Beliefs, Institutions, and Political Change. Ithaca: 235-64.

Krasner, S. (1999) Sovereignty: Organised Hypocrisy. Princeton: Princeton University Press.

Lavin, D. (1982) Lionel Curtis and the Idea of the Commonwealth. In: F. Madden and D. Fieldhouse (eds.) Oxford and the Idea of the Commonwealth. London: Croom Helm.

Lewis, J. (2003) Changing Direction: British Military Planning for Post-war Strategic Defence, 1942-1947. London: Frank Cass.

Long, B. (1937) The Empire: Now. In: A. Willert et al. (eds.) The Empire in the World: A Study in Leadership and Reconstruction. London: Oxford University Press, 80-92.

Louis, Wm. R. (1977) Imperialism at Bay: The United States and the Decolonization of the British Empire, 1941-1945. Oxford: Oxford University Press.

Macleod, I. (1961) Neville Chamberlain. London: Frederick Muller.

Mann, M. (1993) The Sources of Social Power, vol. 2, The Rise of Classes and NationStates, 1760-1914. Cambridge: Cambridge University Press.

Mansergh, N. (1952) Survey of British Commonwealth Affairs, vol. I, Problems of External Policy, 1931-1939. London: Oxford University Press.

Martel, G. (2000), Decolonisation after Suez: Retreat or Rationalisation? Australian Journal of Politics and History 46(3), 403-17.

Metcalf, T. (2005) Forging the Raj: Essays on British India in the Heyday of Empire. Oxford: Oxford University Press.

Morgenthau, H. (1978) Politics among Nations: The Struggle for Power and Peace. New York: Knopf.

Nicholls, G. (1961) South Africa in My Time. London: Allen and Unwin.

Ovendale, R. (1975) 'Appeasement' and the English Speaking World. Cardiff: University of Wales Press. 
Pakenham, T. (1979) The Boer War. London: Weidenfeld and Nicolson.

Palmer, G. (1934) Consultation and Co-operation in the British Commonwealth. London: Oxford University Press.

Peden, G. (1979) British Rearmament and the Treasury. Edinburgh: Scottish Academic Press.

Petersen, T. (2000) Crossing the Rubicon? Britain's withdrawal from the Middle East, 1964-1968: A Bibliographical Review. The International History Review 22(2): 318-40.

Pollard, A. (1919) The League of Nations in History. In: Viscount Grey (ed.) The League of Nations. Oxford: Oxford University Press, 37-58.

Report of a meeting at Balliol College (1942). National Archives: FO 371/31500.

Reynolds, D. (1991) Britannia Overruled: British Policy and World Power in the Twentieth Century. London: Longman.

Reynolds, W. (2000) Australia's Bid for the Atomic Bomb. Melbourne: Melbourne University Press.

Rooth, T. (1986) Imperial Preference and Anglo-Canadian Trade Relations in the 1930's: The End of an Illusion? British Journal of Canadian Studies 1(2): 205-229.

The Round Table (1938) British Commonwealth Relations. 28(110).

Rosenberg, J. (1994) The Empire of Civil Society: A Critique of the Realist Theory of International Relations. London: Verso.

Ruggie, J. (1993) Territoriality and Beyond: Problematizing Modernity in International Relations. International Organization 47(1): 139-174.

Rumilly, R. (1973) Maurice Duplessis et Son Temps. Montréal: Fides.

Seymour, C. (1926) The Intimate Papers of Colonel House. London: Ernest Benn.

Smuts, J. (1918) The League of Nations: A Practical Suggestion. London: Hodder \& Stoughton.

Spruyt, H. (1994) The Sovereign State and its Competitors. Princeton: Princeton University Press.

Spruyt, H. (2005) Ending Empire: Contested Sovereignty and Territorial Partition. Ithaca: Cornell University Press.

Statute of Westminster (1931). In: Darwin, J. and Madden, F. (eds.) Select Documents on the Constitutional History of the British Empire and Commonwealth, vol. VI, The Dominions and India since 1900. London: Greenwood. 
Strachan, H. (2001) The First World War. Oxford: Oxford University Press.

Taylor, A. (1992) English History, 1914-1945. Oxford: Oxford University Press.

Teschke, B. (2003) The Myth of 1648: Class, Geopolitics and the Making of Modern International Relations. London: Verso.

Tilly, C. (1992) Coercion, Capital and European States, A.D. 990-1992. Oxford: Blackwell.

Trevelyan, G. (1940) Grey of Fallodon. London: Longman.

Ward, S. (2001) Australia and the British Embrace: The Demise of the Imperial Ideal. Melbourne: Melbourne University Press.

Watt, D. (1965) Personalities and Policies: Studies in the Formulation of British Foreign Policy in the Twentieth Century. London: Longman.

Woolf, L. (1916) International Government. London: George Allen \& Unwin.

Zimmern, A. (1934) The Third British Empire. Oxford: Oxford University Press. 